\title{
ヒンダードフェノール系低分子化合物と塩素化ポリエチレンからなる 有機ハイブリッドの動的粘弾性
}

吳 馳飛*1 · 山岸忠明*1 · 中本 義章*1 ·石田 眞一郎*1

新田 晃平*2 $\cdot$ 䜃田 三郎 ${ }^{* 3}$

(受付 1999 年 12 月 24 日·審査終了 2000 年 2 月 7 日)

\begin{abstract}
要 旨 塩素化ポリエチレン（CPE）とヒンダードフェノール系低分子化合物（AO-80）から なる有機ハイブリッド（CPE/AO-80）の動的粘弾性を測定した. CPE/AO-80 は, CPEのガラス 転移点より高い温度でもう 1 つ非常に大きな緩和を示した。この緩和は, AO-80の充てん量の

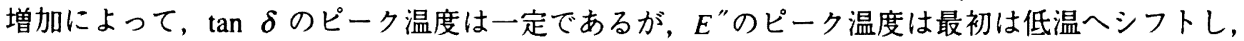
ある臨界值を超えたら，一定となることがわかった。一方，示差走査熱量測定（DSC）曲線上の ジャンプの補外開始温度は線形的に高温へシフトする。ささらに，その緩和温度は測定時加えられ た振動の振幅にも依存する。この種の材料は極めて高い制振性や形状記憶特性を有することがわ かった.
\end{abstract}

\section{1 序言}

高分子が実際に材料として使われるためには種々の添 加剤が必要である。従来，ゴムやプラスチック等の高分 子に添加される各種低分子化合物は高分子の改質に限ら れて使われてきたが，その使用量も通常わずか数 $\mathrm{wt} \%$ に過ぎない，最近，高分子に種々の低分子化合物を多量 に複合させ，酸塩基結合や水素結合等の非共有結合を巧 みに制御し，高分子と低分子を比較的に緩やかに集合・ 組織化することにより新たな性質や機能をもたせること が行われている1)-4). 筆者らは, 極性官能基（側鎖）を もつポリマーに従来架橋促進郕や酸化防止剂として使わ れてきた多官能性のアミン類やフェノール類等の低分子 化合物を分散した有機ハイブリッド系は優れた制振特性 や形状記憶性をもつことを発見した ${ }^{-5)-8)}$. 特にヒンダー ドフェノール系低分子化合物と塩素化ポリエチレン (CPE) からなる有機ハイブリッドには，低分子を含有 する高分子リッチの連続相と高分子の鎖も含まれる低分 子リッチのドメインが存在し, ベースポリマーのガラス 転移点より高い温度でこの低分子リッチ相に起因する新

*1 金沢大学工学部物質化学工学科 (画920-8667 金沢市小立野 240-20)

*2 北陸先端科学技術大学院大学材料科学研究科 (-923-1292 石 川県能美郡辰口町旭台 1-1)

*3. 富山県工業技術センター中央研究所（⑨33-0981 高岡市二上 町 150 番地)
たな緩和が見られだ、ささらに、このような有機ハイブ リッドでは, 相分離特性と動的粘弾性は添加した低分子 化合物の化学構造にも依存することを明らかにした8). 高分子と低分子の間に形成された水素結合が弱くて, 低 分子のコンホーメーションが極めて多い系では, 低分子 ドメインに高分子の鎖を含まず，単一の緩和しか見られ なかった，一方，同じょうに 2 つ緩和を示す系でも， 異分子間の水素結合が比較的に弱くて, 低分子のコンホ ーメーションが多い系では, 放置時間の増加とともに, 高温側の緩和が徐々に小さくなる現象が見られた。これ は高分子と低分子との水素結合が解離され, 代わりに低 分子どうしの水素結合が形成され，その後低分子の結晶 化が起こったためである．したがって，低分子リッチ相 における異分子間の水素結合と低分子どうしの水素結合 の考察により, 高温側の緩和のメカニズムの解明ができ ると考えられる．本報では，低分子化合物の充てん量を 変えて, 動的粘弾性を測定し, 高温側の緩和の大きさ, 位置およびそのひずみ振幅依存性についての考察からそ のメカニズムを明らかにすることを目的とする。

\section{2 実験}

\section{1 試料の作製}

マトリックス高分子としては塩素化ポリエチレン (CPE, 昭和電工(株)エラスレン $401 \mathrm{~A}$, 塩素量は 40 wt \%), 低分子としては Fig. 1 に示す 3,9 ビス [1,1-ジメ チル-2\{ $\beta$-(3-t-ブチル-4-ハイドロキシー5-メチルフェ 


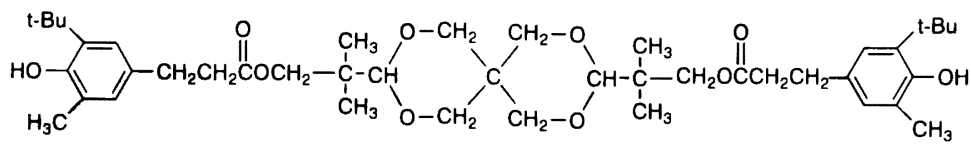

Fig. 1. Chemical structure of 3,9-bis[1,1-dimethyl-2\{ $\beta$-(3-tert-butyl-4-hydroxy-5methylphenyl) propionyloxy (ethyl] $-2,4,8,10$-tetraoxaspiro $[5,5]$-undecane, which is abbreviated as AO-80.

ニル)プロピオニルキシ\}エチル]-2, 4, 8, 10-テトラオキ サスピロ $[5,5]$-ウンデカン, 旭電化工業(株)アデカス夕 ブAO-80)を用いた. AO-80 の性状として, 分子量は 741 であり, ガラス転移温度, 水素結合の解離温度および融

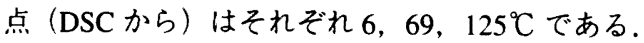

混練はミニロールを用いて約 $50^{\circ} \mathrm{C} て ゙$ 行った。まず, $\mathrm{CPE}$ のみを 5 分混練し, 続けて AO-80 を入れ約 10 分間 混練して十分に分散させた。 それを熱プレスで $160^{\circ} \mathrm{C}$, $200 \mathrm{~kg} / \mathrm{cm}^{2}$ の圧力下で 10 分間保持した後, 水水中で急

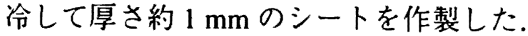

\section{2 動的粘弾性測定}

得られたシートから $20 \times 5 \mathrm{~mm}^{2}$ のサンプルを切り出 し, 動的粘弾性測定装置 (レオロジー(株), DVE-V 4) を用いて試料の動的粘弾性を測定した. 測定条件として, 升温速度は $3^{\circ} \mathrm{C} / \mathrm{min}$, 周波数は 11 と $1.1 \mathrm{~Hz}$ ，振幅は 10 $\mu$, 測定モードは引張りである。

\section{3 ガラス転移温度の測定}

$\mathrm{CPE}, \mathrm{AO}-80$ および CPE AO-80 のガラス転移温度の 測定には示差走査熱量測定装置 (DSC-7 Perkin-Elmer calorimeter）を用いた。 約 $20 \mathrm{mg}$ の試料を試料パンに入 れ， $50^{\circ} \mathrm{C}$ から $-100^{\circ} \mathrm{C}$ まで急冷してから昇温速度 $10^{\circ} \mathrm{C} /$ min 転移温度として測定した。

\section{4 電子顕微鏡観察}

試料の表面にイオンスパッタ蒸着装置（HITACHI E1030）を用いて厚さ䄪 $25 \mathrm{~nm}$ の Pt-Pd 層を蒸着した後, 走査型電子顕微鏡（HITACHI S-4500）で CPE/AO-80の 相分離状態を観察した。

\section{3 結果と考察}

Fig. 2 に CPE および $\mathrm{CPE} / \mathrm{AO}-80$ の損失正接 $\tan \delta$ の 温度依存性を示す。 $12^{\circ} \mathrm{C}$ 前後で見られるべースポリマ 一 CPEのガラス転移に加えて，65ㅇ あたりにもう1つ 新しいピークが見られる。これは，CPE/AO-80は相分 離系であることを示唆している，CPE/AO-80 (50 wt \%) の SEM 写真を Fig. 3 に示す。この試料においては, は っきりした相分離が見られ，AO-80のドメインのサイ ズはサブミクロンオーダーであることがわかった.

Bazuin らはポリ(4-ビニルビリジン)/カルボン酸で末端

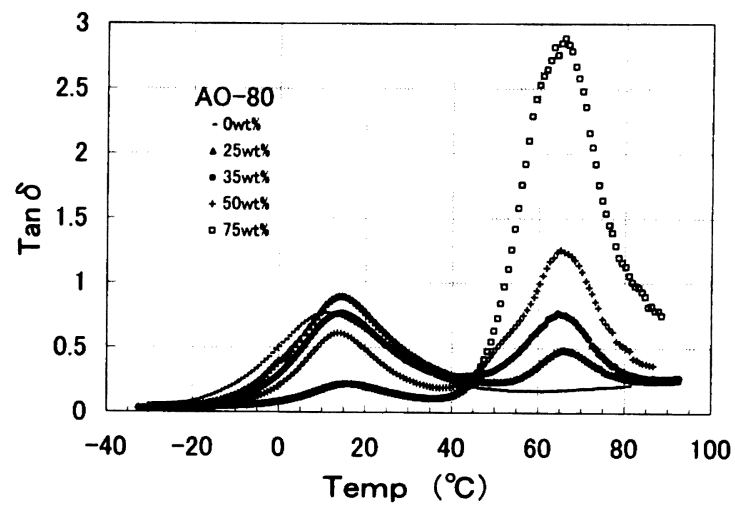

Fig. 2. Temperature dependence of $\tan \delta$ at $11 \mathrm{~Hz}$ for $\mathrm{CPE}$, and $\mathrm{CPE} / \mathrm{AO}-80$.

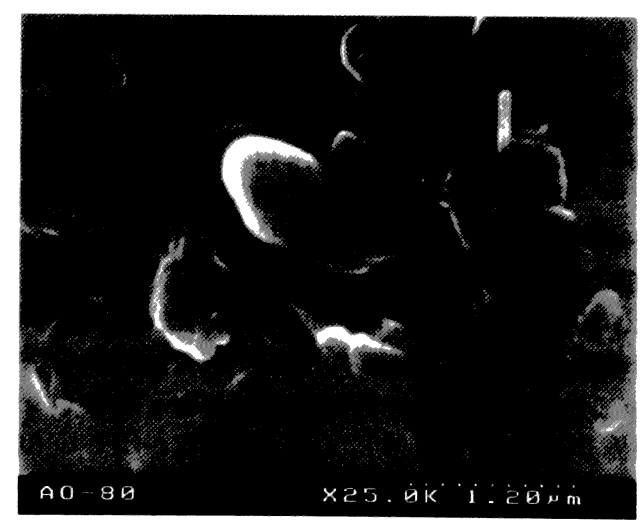

Fig. 3. SEM photograph of CPE/AO-80 (50 wt \%)

処理したメソゲン複合体では高分子が取り込まれている 低分子リッチの構造が存在していることを報告した9). $\mathrm{CPE} / \mathrm{AO}-80$ では同様な構造が存在しているかどうかは, この AO-80のドメインについての局所の元素分析がで きれば，判明できる。しかし，実際に，比較的に強いX 線（CPEの塩素を検出するため）を AO-80のドメイン に当てると，そのドメインがすぐ融けるため，元素分析 


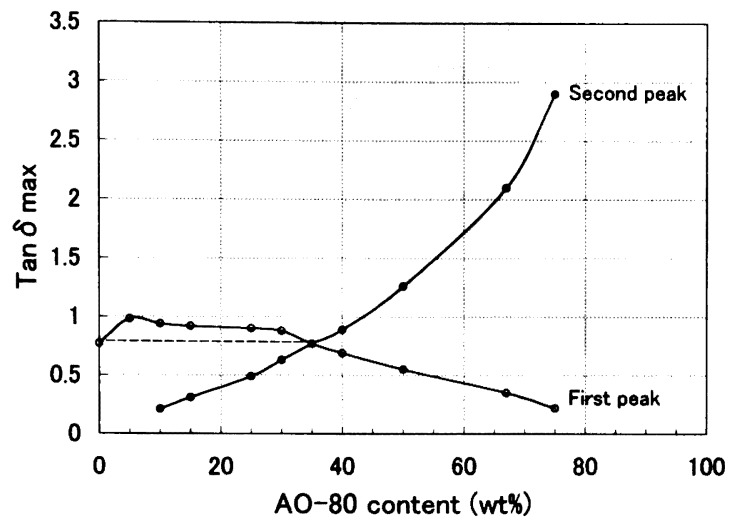

Fig. 4. Dependence of $\tan \delta$ peak maximum of CPE/AO80 on AO- 80 content.

はできなかった，一方，CPEとその他のヒンダードフ エノール系低分子化合物（例えば，テトラキス [メチレ ン-3-(3', 5'-ジ-tーブチル-4-ヒドロキシー5-メチルフェ ニル）プロピオネート，AO-60）からなる系では， AO60 のドメインに塩素が検出された8).このことから， $\mathrm{CPE} / \mathrm{AO}-80$ にも AO-80のドメインに CPEの分子鎖が取 り込まれていると推定できる。 また，FT-IR スペクトル には，純 AO-80はフリーのヒドロキシル基と自己会合 のヒドロキシル基の伸縮振動による2つの吸収を示すの に対して, $\mathrm{CPE} / \mathrm{AO}-80$ は自他会合のヒドロキシル基に よる吸収しか示さなかっだ、このことは，ほとんどの $\mathrm{AO}-80$ 分子は水素結合により $\mathrm{CPE}$ の分子鎖と結ばれて いることを意味し，上記の推定を確認した. したがって， $\mathrm{CPE} / \mathrm{AO}-80$ は, 一般のポリマーブレンドとは違って, AO-80のドメインにCPEの鎖が取り込まれており，CPE と AO-80 は完全に相分離をしておらず，部分的に混合 していると考えられる.

Fig. 2 から $\tan \delta$ ピークの高さと AO-80の充てん量と の関係を整理し, Fig. 4 にプロットした. CPEにAO-80 を充てんしていくと，CPEのガラス転移に起因する低 温ピークは，最初は少し大きくなり，その後だんだん低 下していくことが見られる.ポリマーブレンドの場合， 相溶しない 2 相混合系においては，ある相による $\tan \delta$ のピークがその相の容積分率に比例して小さくなるのは 普通である。ところが, CPE/AO-80 系においては AO-80 の充てん量が $35 \mathrm{wt} \%$ まではベースポリマーのそれより も大きい. 同様な傾向は $\mathrm{CPE} / \mathrm{AO}-60$ にも観察された8). CPEの連続相にAO-60の酸素が検出された結果から, $\mathrm{CPE}$ の連続相にも一部の $\mathrm{AO}-60$ 分子が分散されている ことがわかった。したがって，CPE/AO 80 においても， CPE の連続相に一部の AO-80 分子が分散されているこ

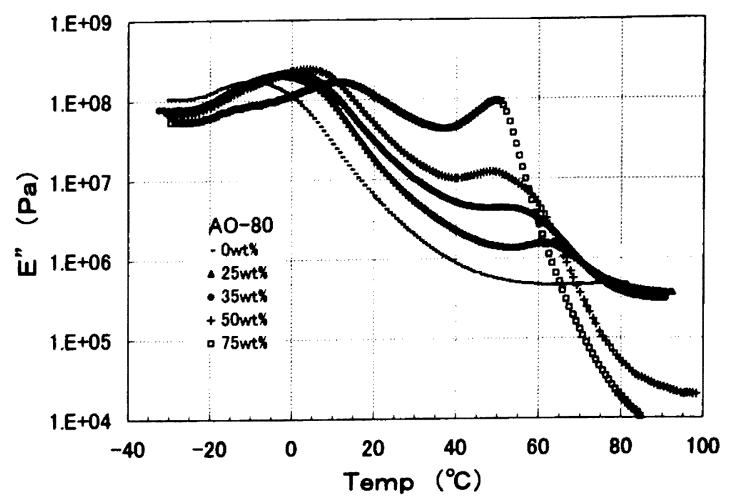

Fig. 5. Temperature dependence of $E^{\prime \prime}$ at $11 \mathrm{~Hz}$ for $\mathrm{CPE}$, and $\mathrm{CPE} / \mathrm{AO}-80$.

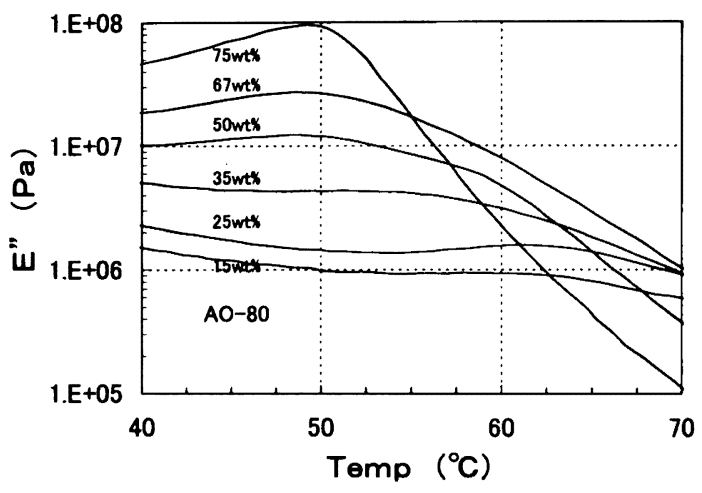

Fig. 6. Temperature dependence of $E^{\prime \prime}$ at $11 \mathrm{~Hz}$ for CPE, and $\mathrm{CPE} / \mathrm{AO}-80$.

とは言える.以上の結果をまとめてみると,CPECPE/AO80 には 2 つの相互貫通の相, すなわち CPEリッチ相と $\mathrm{AO}-80$ リッチ相が存在し, $\tan \delta$ の最初のピークは CPE リッチ相によるもの, 2つ目のピークはAO-80リッチ 相によるものであると推定できる。一方, Fig. 4 から, 高温側のピークは AO-80 の充てん量が $10 \mathrm{wt} \%$ 程度のと ころで発現し，その後顕著に增加し， $35 \mathrm{wt} \%$ とき低 温ピークを超え, $75 \mathrm{wt} \%$ のと， 3 近くまでも達してい ることも見られる。しし高温側のピークが AO-80リッ チ相によるものなら, 当然ながら, AO-80の増加とと もに大きくなるはずである. 本研究では, 以後主に AO80 リッチのドメインに由来する高温側のピークに着目 する。

Fig. 5 に CPE, $\mathrm{CPE} / \mathrm{AO}-80$ の損失弾性率 $E^{\prime \prime}$ の温度依 存性を示す．図より明らかなように，はっきりした2つ のピークが見られる. 各試料の $E^{\prime \prime}$ 高温ピークの詳細 


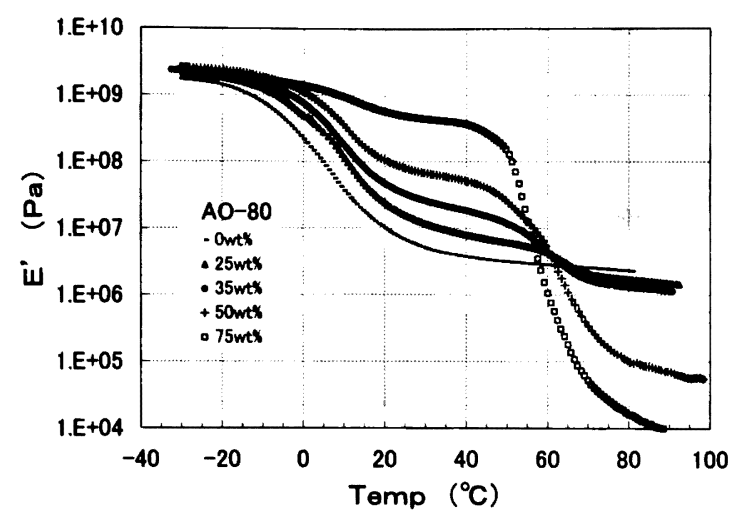

Fig. 7. Temperature dependence of $E^{\prime}$ at $11 \mathrm{~Hz}$ for CPE, and $\mathrm{CPE} / \mathrm{AO}-80$.

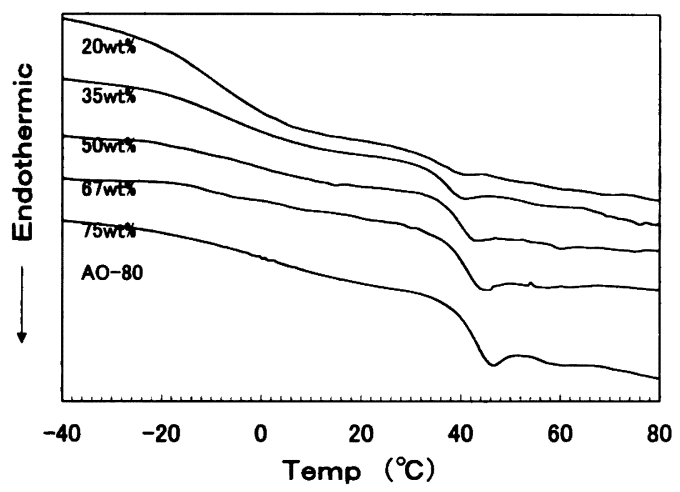

Fig. 8. DSC thermograms of $\mathrm{CPE} / \mathrm{AO}-80$. Scan rate was $10^{\circ} \mathrm{C} \min ^{-1}$.

を Fig. 6 に示す. Fig. 2 からは, $\tan \delta$ のピーク温度は AO-80 の充てん量に依存せず一定であることが見られ た。一方， $E$ "の場合は，AO-80の充てん量が $25 \mathrm{wt} \%$ ま で $61{ }^{\circ} \mathrm{C}$ の付近にはっきりしたピークを示し，その後は 平坦な領域を示し, $50 \mathrm{wt} \%$ を超えると, $49^{\circ} \mathrm{C}$ 近辺で再 びはっきりしたピークが現れた。このような特性はアイ オノマーでよく見られたように，クラスター相に起因す る緩和がイオンの増加につれて高温へシフトしていくこ と(0).11) とは異なる.アイオノマーの場合, 高温側のピ ークも通常のガラス転移によるものと解釈されてい $ろ^{(2)}$. したがって, CPE/AO-80の場合では, 高温側の ピークはガラス転移とは異なる緩和によるものであると 考えられる.

Fig. 7 にCPE および CPE/AO-80の貯蔵弾性率 $E^{\prime}$ の 温度依存性を示す。これからも，高温側の緩和は AO-80 の充てん量の増加につれて低温へシフトしていく傾向が

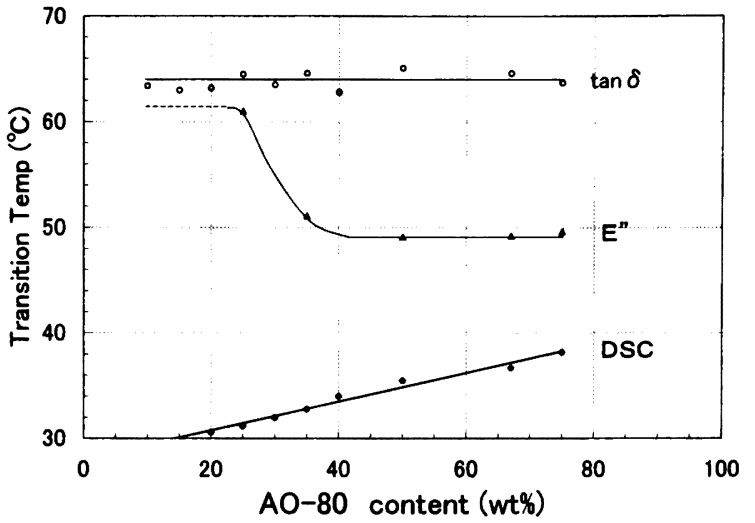

Fig. 9. Second transition temperature obtained from the peak maximum of $E^{\prime \prime}$ and $\tan \delta$ at $11 \mathrm{~Hz}$, and DSC at 10 ${ }^{\circ} \mathrm{C} \min ^{-1}$ as a function of $\mathrm{AO}-80$ content for $\mathrm{CPE} / \mathrm{AO}-80$.

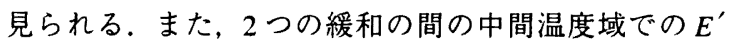
がだんだん上昇していくことも見られる。ベースポリマ 一 CPEの $E^{\prime} に$ に比べて上昇した部分は, AO-80リッチの ドメインが単にフィラーとして働くと考えると, Goth 式13) だけでは説明できない7)。このことから，フィラー の充てん効果のほかに架橋点として働いていることも想 定できる.

高温側の粘弾性ピークの AO-80 充てん量依存の特異 性をより詳細に調べるために, DSC 測定を行い, その 結果を Fig. 8 に示す. DSC 曲線からも，はっきりした 2 つの緩和が見られ, 動的粘弾性の測定結果とよく一致す る. 前述のように, 高温側の緩和が $\mathrm{AO}-80$ リッチのド メインによるものであれば，その強度は AO-80の充て ん量の増加につれて徐々に大きくなるはずである. 実際, 緩和強度を反映する熱量のジャンプは確かに大きくなっ ていくように見られ, $\tan \delta$ のピーク値の充てん量依存 性とよく対応する。また, 高温側の緩和の温度範囲も AO-80が多いほど狭い. 特に, CPEリッチの連続相に よるガラス転移に比べて極めて狭い，これは，高温側の 緩和は CPE と AO-80 の間に形成された水素結合の解離 に伴った単一緩和過程であることを示唆している。もし そうであるならば, その位置は変わらないはずである。 しかし, 害際に高温側の緩和の位置は高温へシフトし,

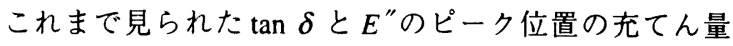
依存性とは一致しない。この緩和温度の測定法による不 一致は今まで多くの系で見られた傾向とは違って, 注目 すべきであると考えられる。

動的粘弾性の $\tan \delta$ と $E^{\prime \prime}$ のピーク温度から,また DSC の熱量ジャンプから読みとった高温側の緩和温度の AO-80の充てん量依存性をまとめて, Fig. 9 に示す。緩 
和温度の測定法による不一致が目立つように見られる。 $\mathrm{AO}-80$ の充てん量の増加とともに, $\tan \delta$ のピーク温度

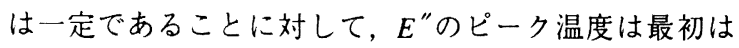
低温にシフトし，ある臨界值を超えたら，一定であるが, DSC の熱量のジャンプ開始温度は線形的に高温へシフ トする.

ここでまずDSCの測定結果から考察する。緩和の熱 分析曲線の形状はその分子構造の微細な差異によって著 しく変化するので, 重要な情報となりうる. Fig. 8 に示 したDSC 曲線から，緩和の終わりに吸熱のピークが見 られる。このピークはAO-80 リッチのドメインの緻密 化に起因すると解釈できる. DSC 曲線上のジャンプは $\mathrm{CPE}$ の $\alpha$ 水素と $\mathrm{AO}-80$ のヒドロキシル基との間に形成 された水素結合の解離によるものに対して，その後現れ た吸熱ピークはAO-80 分子どうしの水素結合の形成に より緻密化した AO-80リッチのドメインの急激な体積 増加によるものと考えられる。この吸熱ピークは AO-80 が多いほど大きくなるということは, AO-80リッチの ドメイン構造は AO-80の量により微妙に変わることを 意味する，言い換えると，充てん量が低い場合，AO-80 リッチのドメインはほとんど異分子間の水素結合で結ば れているのに対して, 充てん量が高い場合, AO-80リ ッチのドメインは異分子間の水素結合以外に低分子どう しの水素結合も寄与している。 また, DSC 曲線上のジ ヤンプ位置の高温へのシフトも, AO-80 分子どうしの 水素結合が増加したためであると考えられる。

次に $E "$ のピーク温度の AO-80 充てん量依存性に焦点 を当てる.ゴムの動的粘弾性はひずみ振幅に依存しない が, カーボンブラックを配合したゴムの貯蔵弾性率はひ ずみ振幅の増加とともに低下し, 非充てん架橋ゴムの值 に近づく。これは, Payne effect(1) としてょく知られて おり，ゴム中に分散したカーボンアグリゲードが形成し ている網目構造の破壊に起因すると説明されている. $\mathrm{CPE} / \mathrm{AO}-80$ の場合, 前述のように, 2 つの緩和の間の $E^{\prime}$ が充てん量の増加とともに顕著に増加していくことか ら, AO-80リッチのドメインは物理的架橋としても㗢 いていることがわかったＡＯ-80のドメインを貫通す るCPEの鎖により繁がった AO-80のドメインは実は一 種の網目構造と見なすこともできる。 また，その緩和温 度より低い温度においても, 加えた変形を大きくすれば, 高分子と低分子との間にできた水素結合が解離され, 眝 蔵弾性率 $E^{\prime}$ は低下していくと推察できる。したがって, $\mathrm{CPE} / \mathrm{AO}-80$ において, その動的粘弾性はひずみ振幅に も依存すると考えられる. Fig. 10 にひずみ振幅の異な る $\mathrm{CPE} / \mathrm{AO}-80(25 \mathrm{wt} \%)$ の損失弾性率 $E^{\prime \prime}$ の温度依存 性を示す。ひずみ振幅の大きいときのE"ピークの低温 へのシフトが見られる。このことから, 高温側の緩和の 位置はひずみ振幅にも依存することがわかった。

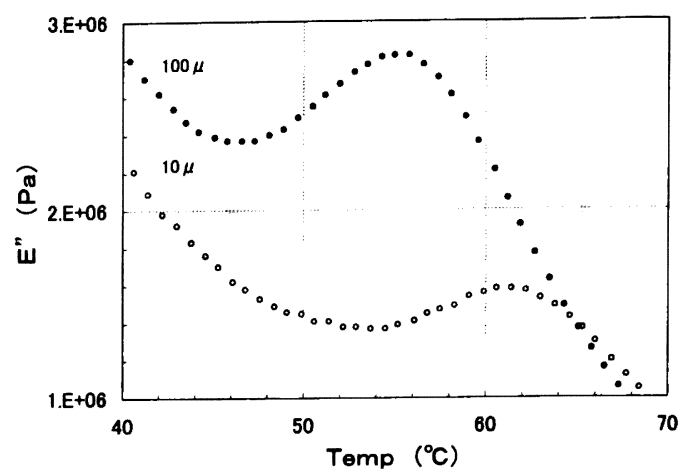

Fig. 10. Temperature dependence of $E^{\prime}$ at $11 \mathrm{~Hz}$ for CPE/ $\mathrm{AO}-80(25 \mathrm{wt} \%)$. The amplitude of the vibrational wave is indicated for each curve.

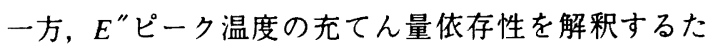
めに，巨視的な変形を微視的な分子レベルでの変形と一 緒に考える必要がある．相分離した CPE/AO-80におい て, AO-80リッチのドメインが比較的硬くて, 変形しに くいとすると, 高充てんの場合, 同じひずみ振幅を試料 に加えるとしても，実際に局所のCPEの鎖に受ける変 形は低充てんの場合に比べてかなり大きい.したがって，

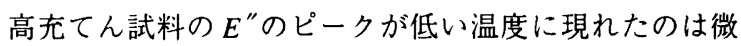
視的な分子の変形が大きいためであると解釈できた。

最後に, 注目すべきことは高温側の緩和の大きさであ る. 低分子結晶の融解のような 1 次転移の場合, 転移範 囲も極めて狭いが, この転移によりもたらされた $\tan \delta$ のピークはそれほど大きくない(15),16).このような 1 次 転移を示す系と本研究の $\mathrm{CPE} / \mathrm{AO}-80$ 系を比較すると, $\mathrm{CPE} / \mathrm{AO}-80$ の場合非常に大きい $\tan \delta$ ピークを示すこ とが見られた。 CPE/AO-80においては，AO-80の結晶 が存在しない7ため, 高い $\tan \delta$ を示すのは, 結晶融解 のような 1 次転移とは関係せず, 高分子が低分子のドメ インを貫通するような低分子リッチの形成に起因するこ とがわかった。また，この大きな緩和を生かして，今ま で得られなかった, 新たな機能性材料, 例えば, $\tan \delta$ が 温度に依存しない高減衰材料, 形状記憶ゴム, 新規の熱 可塑性エラストマーなどを生み出すことが可能である.

\section{4 結 論}

塩素化ポリエチレンとヒンダードフェノール系低分子 化合物からなる有機ハイブリッドについて, 動的粘弾性 を調べて次のような結果が得られた。

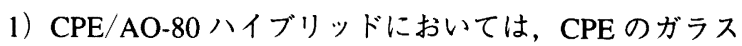
転移温度より高い温度でもう 1 つ非常に大きな緩和が見 られた。この緩和は CPEの鎖を含む AO-80リッチのド メインに起因することがわかった。 
2）この高温側の緩和について，測定方法による䋸和温 度の不一致が見られた. AO-80の充てん量の増加によ って, $\tan \delta$ のピーク温度は一定であるが, $E^{\prime \prime の ヒ ゚ ー ク ~}$ 温度は充てん量が少ないときは低温へシフトし，ある臨 界值を超えたら，一定となった。これは緩和温度のひず み振幅依存性と局所の CPE の鎖に加えられたひずみの 大きさから解釈できる。一方, DSCの熱量のジャンプ 補外開始位置の高温へのシフトは低分子どうしの水素結 合の増加によるものであると考えられる。

以上により，この転移を高分子材料の設計に持ち込む ことによって, 制振性が極めて高い新素材や形状記憶ゴ 么等の新規機能性材料が得られると考えられる.

謝辞 本研究は(財) 北陸産業活性化センターの研究助成を受 けて行われたものである。ここに厚く謝意を表します。

\section{文献}

1) C. Wu, M. Sumita, K. Inoue, and S. Asai, Rep. Progr. Phys. Jpn., 41, 457 (1998)

2）古川猛夫, 高橋芳行, 堀 光雄、大平康幸, 高分子学会予稿集, 47, 3959 (1998).

3）金子核, 浅井茂雄, 住田雅夫, 井上清博, 䄉維学会予稿集, F172 (1998).
4）宴 雄、浅井茂雄、住田雅夫，高分子学会予稿集，48、1051 (1999).

5）吳 殹飛, 山岸忠明, 中本義章, 石田真一郎, 高分子学会予稿集, 48, 4167 (1999).

6) C. Wu, T. Yamagishi, Y. Nakamoto, S. Ishida, K. Nitta, and S. Kubuta, J. Polym. Sci. B : Polym. Phys., in press

7) C. Wu, T. Yamagishi, Y. Nakamoto, S. Ishida, K. Nitta, and S. Kubuta, J. Polym. Sci. B : Polym. Phys., to be submitted.

8) C. Wu, T. Yamagishi, Y. Nakamoto, S. Ishida, K. Nitta, and S. Kubuta, J. Polym. Sci. B : Polym. Phys., in press.

9) A. Frank, A. Brandys, and C. G. Bazuin, Chem. Mater., 8, 83 (1996).

10) L. Dulac and C. G. Bazuin, Acta Polym., 48, 25 (1997).

11) J. S. Kim, R. J. Jackman, and A. Eisenberg, Macromolecules, 27, 2789 (1994).

12) D. Rahring, C. Azuma, and W. Macknight, J. Polym. Sci., Polym. Phys. Ed., 16, 59 (1978)

13) E. Guth, J. Appl. Phys., 16, 20 (1945).

14) A. R. Payne and R. E. Whittaker, Rubber Chem. Technol., 44, 440 (1971).

15）辻田義治, 機能材料, 18 (4), 24 (1998)

16）吳 馳飛, 山岸忠明, 中本義章, 石田真一郎, 新田晃平, 窪田三 郎, エラストマー討論会予稿集, 12,18 (1999)

\section{Viscoelastic Properties of Organic Hybrids Consisting of Chlorinated Polyethylene and Hindered Phenol}

Chifei WU ${ }^{* 1}$, Tadaaki Yamagishi ${ }^{* 1}$, Yoshiaki NaKamoto ${ }^{* 1}$, Shinichiro Ishida ${ }^{* 1}$, Kohhei NitTa ${ }^{* 2}$, and Saburo KubOta ${ }^{* 3}$

*'Department of Chemistry and Chemical Engineering, Kanazawa University (Kodatsuno, Kanazawa, Ishikawa, 920-8667 Japan)

${ }^{*}$ School of Materials Science, Japan Advanced Institute of Science and Technology (Tatsukuchi, Ishikawa, 923-1292 Japan)

${ }^{*}$ Toyama Industrial Technology Center (Futagami, Takaoka, Toyama, 939-0981 Japan)

Viscoelastic properties of an organic hybrid consisting of chlorinated polyethylene (CPE) and 3,9-bis[1,1-dimethyl-2\{ $\beta$-(3-tertbutyl-4-hydroxy-5-methylphenyl) propionyloxy\}ethyl]-2,4,8,10-tetraoxaspiro[5,5]-undecane (AO-80) are investigated. For CPE/AO-80 hybrid, a new transition in viscoelastic properties is observed above the glass transition temperature of CPE matrix. With increasing AO80 content, the second peak position of the loss modulus shifts to lower temperature and then stands still, but the second transition temperature observed from the DSC increases linearly. The second transition also depends on the amplitude of the vibrational wave. CPE/ AO-80 hybrid has a good damping property and a shape memory effect.

KEY WORDS Chlorinated Polyethylene / Hindered Phenol / Organic Hybrid / Viscoelastic Properties / Damping Properties / Shape Memory Effect / Glass Transition / Hydrogen Bond / Microstracture / Mesophase /

(Received December 24, 1999 : Accepted February 7, 2000)

[Kobunshi Ronbunshu, 57 (5), 294-299 (2000)] 